\title{
The Integrated Health Posts Have Contextual Effect on Maternal Practice of Providing Complementary Feeding
}

\author{
Renidya Asyura Muttabi' Deya Fa'ni'), Yulia Lanti Retno Dewi²), Isna Qadrijati²) \\ 1)Masters Program in Public Health, Universitas Sebelas Maret \\ ${ }^{2)}$ Medical Faculty, Universitas Sebelas Maret
}

\section{ABSTRACT}

Background: Age 0-24 months is a period of rapid growth and development, or also known as the golden period as well as a critical period. The golden period can be realized if during this period infants and children obtain appropriate nutrition for optimal growth and development. The highest prevalence of toddlers of BGM (below the red line) in 2017 is found in Gunungkidul Regency by $1.24 \%$. This study aimed to analyze the determinants of providing MP-ASI at the individual level and posyandu level.

Subjects and Method: This research was conducted using a cross sectional research design. The study was conducted in Gunungkidul Regency from October to November 2019. Sampling was conducted using probability sampling with a number of 200 mothers who have children aged 6-24 months. The dependent variable is the practice of complementary feeding. The independent variables were birth weight, nutritional status, maternal knowledge toward complementary feeding, maternal education, and family income. Data were collected using a questionnaire, weight scales, and height gauges. Data were analyzed by a multiple multilevel logistic regression.

Results: Good Complementary feeding practice increased with birth weight $\geq 2500$ grams $(b=$
$2.51 ; 95 \% \mathrm{CI}=0.57$ to $4.66 ; \mathrm{p}=0.012$ ), normal child nutritional status $(\mathrm{b}=2.18 ; 95 \% \mathrm{CI}=0.33$ to $6.42 ; \mathrm{p}=0.029$ ), high maternal knowledge toward complementary feeding $(b=2.12 ; 95 \%$ $\mathrm{CI}=0.16$ to $4.38 ; \mathrm{p}=0.034)$, maternal education $\geq$ Senior high school $(b=2.10 ; 95 \% \mathrm{CI}=0.18$ to 5.31; $\mathrm{p}=0.036)$, and high family income $(\mathrm{b}=$ 2.30; 95\% CI=0.34 to 4.32; $\mathrm{p}=0.021$ ). Posyandu had strong contextual effect on complementary feeding practice $(\mathrm{ICC}=\mathbf{2 8 . 0 1} \%)$.

Conclusion: Good Complementary feeding practice increases with normal birth weight, normal child nutritional status, high maternal knowledge, high maternal education, and high family income. Posyandu has strong contextual effect on complementary feeding practice.

Keywords: complementary feeding, integrated health post

\section{Correspondence:}

Renidya Asyura Muttabi' Deya Fa'ni. Masters Program in Public Health, Universitas Sebelas Maret, Surakarta, Jl. Ir. Sutami No. 36 A, 57126, Surakarta, Central Java. Email: renidyamdf@gmail.com. Mobile: +62 81539340421

Cite this as:

Fa'ni RAMD, Dewi YLR, Qadrijati I (2020). The Integrated Health Posts Have Contextual Effect on Maternal Practice of Providing Complementary Feeding. J Matern Child Health. 5(3): 265-274. https://doi.org/10.26911/thejmch.2020.05.03.05

Journal of Maternal and Child Health is licensed under a Creative Commons Attribution-Non Commercial-Share Alike 4.0 International License.

\section{BACKGROUND}

Indonesia is a developing country with complex nutritional problems when referring to high rates of stunting and malnutrition. According to Riskesdas data the prevalence of malnutrition in 2007 was $18.4 \%$ then decreased in 2010 to $17.9 \%$ but experienced an increase again in 2013 of $19.6 \%$. The prevalence of malnutrition in 2007 was $5.4 \%$ decreased in 2010 to $4.9 \%$ then increased again in 2013 to $5.7 \%$ (Basic Health Research, 2013). According to the World Health Organization (WHO), malnutrition results in $54 \%$ of infant and child deaths. The results of 
Fa'ni et al./ Integrated health post and complementary feeding practice

the WHO census show that $49 \%$ of 10.4 million child deaths in developing countries are related to malnutrition. Severe malnutrition rates in the world include 50\% Asian toddlers, 30\% African toddlers, 20\% Latin American toddlers. Therefore, the main priority of the main treatment is to improve feeding to infants and children and improve maternal nutrition ( $\mathrm{MOH}, 2010)$.

Age 0-24 months is a period of rapid growth and development, or also known as the golden period as well as a critical period. The golden period can be realized if during this period infants and children obtain appropriate nutrition for optimal growth and development. Malnourished infants will potentially experience growth and development disorders, if not addressed early can continue into adulthood (Zahraini, 2013). WHO and UNICEF recommend four things to achieve optimal growth in children, namely breastfeeding after 30 minutes the baby is born, exclusive breastfeeding, MP-ASI at the age of 6-24 months, and breastfeeding until the age of 24 months (WHO, 2003).

Complementary feeding is a process of transition from solely milk-based intake to semi-dense foods. The introduction and administration of complementary feeding should be done in stages both in form and amount, according to the digestive ability of infants/ children (Bennu et al., 2012). Providing the right complementary feeding practice is expected to not only meet the nutritional needs of infants, but also stimulate feeding skills and stimulate self-confidence in infants (Indonesian Ministry of Health, 2005).

Supplementary feeding must vary from the form of liquid porridge, thick porridge, fruit juice, fresh fruit, pulverized food, soft food, and finally solid food (Diah, 2001). The provision of sufficient complementary feeding in terms of quality and quantity is important for the physical growth and intelligence development of children who grew rapidly in this period. As the baby's age increases, his nutritional needs also increase, so his milk must be increased so that the baby gets energy for its growth and development. ASI only meets the nutritional needs of infants as much as $60 \%$ in infants aged 6-12 months. The rest must be fulfilled with other foods that are sufficient in number and good nutrition (Bennu et al., 2012). Therefore babies 6 months of age and over need additional nutrients from the complementary feeding, but complementary feeding practice must also be of high quality.

Efforts made in order to reduce the prevalence of protein energy deficiency. Children in Yogyakarta have not been reached to the maximum proven evidence of malnutrition in the amount of 8.83 in 2016 and again dropped to 8.26 in 2017. Gunungkidul has the highest prevalence of low birth weight (LBW) after Kulonprogo which is $5.67 \%$. The highest prevalence of children with nutritional status under red line in 2011 was found in Gunungkidul Regency by $1.24 \%$. On the other hand, the highest prevalence of Stunting in 2017 was also found in Gunung Kidul Regency by $20.60 \%$. In addition, Gunungkidul District had the lowest rate of presentation of babies who received exclusive breastfeeding in 2017 after the city of Yogyakarta, which was $66.75 \%$. These figures are followed by the presentation of human resources with the lowest level of education in DIY, low income of the population and geographical conditions of the mountains with a wide population distribution $(\mathrm{MOH}, 2017)$.

Soetjiningsih (2012) states that nutritional intake (giving, frequency and duration of breastfeeding as well as giving complementary feeding) that affect infant growth is influenced by external factors such as parental education and socioeconomic.

This study aimed to analyze the determinants of providing MP-ASI at the indi- 
Fa'ni et al./ Integrated health post and complementary feeding practice

vidual level and posyandu level.

SUBJECTS AND METHOD

\section{Study Design}

This was a cross sectional study conducted at

25 integrated health posts (posyandu) Gunungkidul Regency, Indonesia, from October to November 2019.

\section{Population and Sample}

The study population was mother who had children aged 6-24 months. A sample of 200 mothers with children aged 6-24 months was selected by probability sampling. At each posyandu unit, 8 mothers were taken.

\section{Study Variables}

The dependent variable was complementary feeding. The independent variables were birth weight, nutritional status, maternal knowledge toward complementary feeding, maternal education, and family income at level 1. Posyandu was contextual effect.

\section{Operational Definition of Variables} Birth weight was the child's body weight measured at birth in gram. The measurement scale was categorical with code $\mathrm{O}=$ low birth weight $<2500$ gram and $1=$ birth weight $\geq 2500$ gram.

Nutritional status was monitoring nutritional status assessed through measurements of a child's weight and height which will then be included in the WHO child growth chart. The measurement scale was categorical, coded $\mathrm{o}=$ underweight -3.0 to $<-2.0 \mathrm{SD}$ and $1=$ normal ( -2.0 to 2.0 SD).

Knowledge toward complementary feeding was information and experience known to mothers related to giving MP-ASI. The measurement scale was continous and transformed into dichotomous, coded $\mathrm{O}=$ low (score $<$ mean) and $1=$ high ( $\geq$ mean score).

Education was the level of formal education that has been taken by mothers, including elementary, junior high, high school and tertiary institutions. The measurement scale was categorical, coded $\mathrm{o}=$ low $(<$ Senior high school) and $1=$ high ( $\geq$ Senior high school). Income was family income (mother and father) based on regency minimum wage (UMK). The measurement scale was continous and transformed into dichotomous, coded $\mathrm{O}=<$ minimum regional wage $(<\mathrm{Rp}$ $1,571,000)$ and $1=\geq$ minimum regional wage ( $\geq$ Rp 1,571,000).

Complementary feeding was the practice of mothers in providing the correct complementary feeding in accordance with the recommendations of Association of Indonesian Pediatrics (IDAI) covering timely, adequate, safe and provided in the right way (responsive feeding and feeding rules). Minimum regional wage $\mathrm{O}=$ poor $($ score $<$ mean) and $1=\operatorname{good}(\geq$ mean score).

\section{Study Instruments}

Data collection techniques are primary data and secondary data. Primary data were obtained using a questionnaire filled out by research subjects. Secondary data was obtained from the Gunungkidul District Health Office in the form of data on mothers who have children aged 6-24 months in Gunungkidul Regency. The instruments used were questionnaires, weight scale, and height measurements.

\section{Data Analysis}

Univariate analysis was performed to see the frequency distribution and characteristics of research subjects. Bivariate analysis was performed using the chi-square test and calculation of odds ratios (OR) with a 95\% confidence level (CI) to examine the relationships between independent variables on the complementary feeding practice. Multivariate analysis was done using multiple multilevel logistic regression.

\section{Research Ethics}

Research ethics includes research approval (informed consent), anonymous (anonymity), confidentiality (confidentiality) and ethical approval (ethical clearance). Ethical clearance in this study was conducted at the Gene- 
Fa'ni et al./ Integrated health post and complementary feeding practice

ral Hospital Dr. Moewardi Surakarta and was declared ethical according to Decree number: 1,286/ XII/ HREC/ 2019.

\section{RESULTS}

\section{Sample Characteristics}

The frequency distribution of the characteristics of the study subjects is described in Table 1.

Table 1 shows that the majority of study subjects aged 20-35 years were 142 subjects (61.0\%). The majority of working mothers were 148 subjects (74.0\%). Most of the mothers had a high school / vocational and tertiary education with 164 subjects (82.0\%). Most of the children aged between 12-24 months were 114 subjects (57.0\%). Most children were female with 128 subjects (64.0\%).

Table 1. Sample Characteristics

\begin{tabular}{llcc}
\hline & Characteristics & n & \% \\
\hline Age & Age <20 years old or $>$ 30 years old & 58 & 29 \\
& Age 20-30 years old & 142 & 71 \\
Occupation & Working & 52 & 26 \\
& Not working & 148 & 74 \\
Education & PS and JHS & 36 & 18 \\
& SHS and Higher Education & 164 & 82 \\
Children Age & 6-12 months & 86 & 43 \\
& 12-24 months & 114 & 57 \\
Children Gender & Male & 72 & 36 \\
& Female & 128 & 64 \\
\hline
\end{tabular}

Table 2. Frequency distribution of study variables

\begin{tabular}{llcc}
\hline Independent Variable & & n & \% \\
\hline Complementary feeding & Poor (score <mean) & 49 & 24.5 \\
practice & Good (score $\geq$ mean) & 151 & 75.5 \\
Children birth weight & Low birthweight (<2500 gram) & 68 & 34.0 \\
& Normal ( $\geq$ 2500 gram) & 132 & 66.0 \\
Children nutritional status & Underweight (Z-Score= -3.0 to <-2.0) & 61 & 30.5 \\
& Normal (Z-Score = -2.0 to 2.0 SD) & 139 & 69.5 \\
Knowledge toward comple- & Poor (score <mean) & 61 & 30.5 \\
mentary feeding & Good (score $\geq$ mean) & 139 & 69.5 \\
Education & Low (<Senior high school) & 36 & 18.0 \\
& High ( $\geq$ Senior high school) & 164 & 82.0 \\
Family Income & $<$ minimum wage (< Rp 1,571,000) & 49 & 24.5 \\
& $\geq$ minimum wage $(\geq \mathrm{Rp} 1,571,000)$ & 151 & 75.5 \\
\hline
\end{tabular}

\section{Univariate analysis}

The univariate analysis of the practice of giving complementaru feeding in this study explains the general description data from each variables, including birth weight, nutritional status, maternal knowledge, maternal education, and income (Table 2).

Table 2 shows the majority of children had birth weight $\geq 2500$ (66.0\%) and normal nutritional status (69.5\%). Maternal knowledge toward complementary feeding were good (69.5\%), 82.0\% mothers attained education $\geq$ Senior high school, had high family income (75.5\%), and provided good complementary feeding practice (75.5\%).

\section{Bivariate analysis}

The analytical test used in this study is the chi-square test, which explains the rela 
Fa'ni et al./ Integrated health post and complementary feeding practice

tionship between the independent variables

toward dependent variable (Table 3).

Table 3. Bivariate analysis of birth weight, nutritional status, maternal knowledge, education, income, and complementary feeding practice

\begin{tabular}{|c|c|c|c|c|c|c|}
\hline \multirow{3}{*}{ Independent Variable } & \multicolumn{4}{|c|}{$\begin{array}{l}\text { Complementary feeding } \\
\text { practice }\end{array}$} & \multirow{3}{*}{$\mathbf{O R}$} & \multirow{3}{*}{$\mathbf{p}$} \\
\hline & \multicolumn{2}{|c|}{ Yes } & \multicolumn{2}{|c|}{ No } & & \\
\hline & $\mathbf{n}$ & $\%$ & $\mathbf{n}$ & $\%$ & & \\
\hline \multicolumn{7}{|l|}{ Children Birth Weight } \\
\hline Low birthweight ( $<2500$ gram $)$ & 29 & 42.6 & 39 & 57.4 & 16.40 & $<0.001$ \\
\hline Normal ( $\geq 2500$ gram) & 122 & 92.42 & 10 & $7 \cdot 58$ & & \\
\hline \multicolumn{7}{|l|}{ Children Nutritional Status } \\
\hline $\begin{array}{l}\text { Underweight }(\mathrm{Z}-\mathrm{Score}=-3.0 \text { to }<-2.0 \mathrm{SD}) \\
\text { Normal }(\mathrm{Z}-\mathrm{Score}=-2.0 \text { to } 2.0 \mathrm{SD})\end{array}$ & 14 & 22.95 & 47 & 77.05 & 22.99 & $<0.001$ \\
\hline $\begin{array}{l}\text { Knowledge toward complementary } \\
\text { feeding }\end{array}$ & 137 & 98.5 & 2 & 1.5 & & \\
\hline Poor (score <mean) & 19 & 31.15 & 42 & 68.85 & 41.68 & $<0.001$ \\
\hline Good (score $\geq$ mean) & 132 & 94.96 & 7 & 5.04 & & \\
\hline \multicolumn{7}{|l|}{ Education } \\
\hline Low ( $<$ Senior high school) & 5 & 13.8 & 31 & 86.2 & 50.28 & $<0.001$ \\
\hline High ( $\geq$ Senior high school) & 146 & 89.03 & 18 & 10.97 & & \\
\hline \multicolumn{7}{|l|}{ Family Income } \\
\hline$<$ minimum wage $(<\operatorname{Rp} 1,571,000)$ & 10 & 20.83 & 38 & 79.17 & 48.70 & $<0.001$ \\
\hline$\geq \operatorname{minimum}$ wage $(\geq \operatorname{Rp} 1,571,000)$ & 141 & 92.76 & 11 & 7.24 & & \\
\hline
\end{tabular}

Table 3 showed that the child's birth weight, child's nutritional status, maternal knowledge toward complementary feeding, maternal education, and family income increased good complementary feeding practice, and they were statistically significant.

Table 4. Multiple multilevel logistic regression analysis on the contextual effect of posyandu on complementary feeding practice

\begin{tabular}{lcccc} 
& Regression & \multicolumn{2}{c}{ 95\% CI } & \\
\cline { 3 - 4 } \multicolumn{1}{c}{ Independent Variable } & $\begin{array}{c}\text { Coefficient } \\
\text { (b) }\end{array}$ & $\begin{array}{c}\text { Lower } \\
\text { Limit }\end{array}$ & $\begin{array}{c}\text { Upper } \\
\text { Limit }\end{array}$ & p \\
\hline Normal birth weight ( $\geq$ 2500 gram) & 2.51 & 0.57 & 4.66 & 0.012 \\
Nutritional status (Z-Score = -2.0 to 2.0 SD) & 2.18 & 0.33 & 6.42 & 0.029 \\
Good knowledge toward complementary feeding & 2.12 & 0.16 & 4.38 & 0.034 \\
Education ( $\geq$ Senior high school) & 2.10 & 0.18 & 5.31 & 0.036 \\
Income ( $\geq$ Rp 1,571,000) & 2.30 & 0.34 & 4.32 & 0.021 \\
n observation= 200 & & & & \\
n group= 25 & & & & \\
Mean of group= 8, min=8, max=8 & & & & \\
Log likelihood= -23.39 & & & & \\
p= 0.012 & & & & \\
ICC= 28.01\% & & & & \\
\hline
\end{tabular}

\section{Multilevel analysis}

Table 4 shows the results of multiple multilevel logistic regression analysis on the contextual effect of posyandu on complementary feeding practice. Table 4 shows that birth weight, nutritional status, maternal know- ledge toward complementary feeding, maternal education, and family income increased good complementary feeding practice.

Analysis of the data at the delivery place 
Fa'ni et al./ Integrated health post and complementary feeding practice

used for infants (Koletzko et al., 2018).

\section{The effects of child nutrition status on complementary feeding practice}

The results of this study indicate that there is an influence between the nutritional status of children on the practice of giving complementary feeding. Mothers who have children with normal mal-nutritional status have the possibility (logodd) for mothers giving complementary feeding with a good amount of 2.18 units compared with children with abnormal nutritional status.

This is in line with the results of study by Lestari et al., (2012) showing that there is a relationship between the nutritional status of children with supplementary feeding. The provision of food that is not right can lead to malnutrition and excessive giving obesity will occur. The pattern of giving complementary feeding is influenced by maternal factors, because it is the mother who plays a very important role in regulating the consumption of the child, which then affects the nutritional status of the child (Putri, 2013; Widyawati et al., 2016).

Provision of diet and food intake that is given to babies should be right both from the type, amount to the nutritional content. Nutritional intake in infants is almost the same as adults who should contain carbohydrates, proteins, vitamins, fats, and vitamins. Food consumed affects one's nutritional status. Consumption of food in the family depends on the amount and type of food purchased, how to cook, distribution in the family, and individual eating habits. Nutrient intake from food provided by mothers is needed for children who are still in infancy (Iguacel et al., 2019; Wardhani, 2018).

Breastfeeding remains an important source of nutrition for infants and young children. This provides about half of the baby's energy needs until one year of age, and up to one third during the second year of life. Breastmilk continues to supply higher quality nutrients than complementary foods, and also a protective factor. Therefore it is recommended that breastfeeding on demand continues with adequate supplementary feeding for up to 2 years or more (WHO, 2009).

\section{The effect of maternal knowledge toward complementary feeding practice}

The results of this study indicate that there is an influence between maternal knowledge toward complementary feeding practice. Mothers who have good knowledge about toward complementary feeding practice had possibility (logodd) to provide good complementary feeding practice 2.12 units higher than those with low knowledge.

The baby must be given enough nutrition for the growth and development of the baby. Parents are encouraged to feed a good companion for their baby, even though most of them do not have knowledge about general complementary feeding and about determining the baby's readiness or tolerance for oral feeding. For parents who want to provide direct care and care for their children, feeding can be a beneficial parenting activity for child growth and development (HerberJonat, 2018).

Mother's knowledge influences exclusive breastfeeding as well as the gift of complementary feeding. Walsh et al. (2015) stated that a good understanding of mothers about complementary feeding will affect the provision of complementary feeding for infants over 6 months. Besides, the lack of understanding of about the sign of the infant readiness to start solid food also greatly affects the provision of complementary feeding.

The knowledge of mothers is also related to the sources of information that mothers get from myths and mass media. Mothers state that the cause of giving complementary feeding to their babies is due to the mother's habit of giving complementary feed- 
Fa'ni et al./ Integrated health post and complementary feeding practice

ing. Parental knowledge about diet, nutrition, and healthy eating habits in early childhood, which can prevent obesity and obesity in childhood and lay a good foundation for future health (Helle et al., 2017; Ginting et al., 2013).

Heryanto (2017) stated that there is a significant relationship between knowledge and the provision of complementary feeding, mothers with good knowledge tend not to give complementary feeding under the age of 6 months compared to mothers whose knowledge is lacking. Respondents with good knowledge, have understood that babies $<6$ months of age should not be given other foods besides breast milk because their digestion is not ready. The better the respondent's knowledge, then it tends not to provide early complementary feeding.

\section{The effect of maternal education on complementary feeding practice}

The results of this study indicate that there is an influence between maternal education on complementary feeding practice. Mothers with higher education have the possibility (logodd) to provide complementary feeding practice 2.10 units higher than mothers with low education.

Education can affect a person's level of knowledge, the higher the level of one's education the easier it is to receive information, so the better his knowledge, but someone who has low education is not necessarily low knowledge. Knowledge is not only obtained from formal education but can also be obtained through non-formal education, such as personal experience, media, environment and health education, so that someone with higher education can be exposed to the disease and vice versa. Knowledge has an influence on complementary feeding (Nurzeza et al., 2015).

Education is one of the factors that can cause complementary feeding. Education influences one's perception to more easily accept new ideas and technologies. A low or moderate level of education will affect the knowledge and understanding of respondents about the provision of complementary feeding is low and conversely the level of education is very high and very high will make the knowledge and understanding of respondents about giving complementary feeding to infants aged 6-12 months better (Helle et al., 2018; Doub et al., 2015; Asare et al., 2018).

\section{The effect of income on complemen- tary feeding practice}

The results of this study indicate that there is an influence between family income on complementary feeding practice. Children with high income family have possibility (logodd) to provide complementary feeding practice 2.30 units higher than those with low family income.

Income is one of the factors related to financial conditions which causes the purchasing power for additional food to be greater. Income can determine the mother to provide additional food for the baby, the better the family economy, the purchasing power of additional food, on the contrary. The level of family income is related to the provision of complementary feeding (Nauli, 2012; Helle et al., 2018).

Higher family income was significantly positive with early bottle feeding and factorymade food. Mothers with lower economic status tend to start breastfeeding too late, discard colostrum and provide pralactal food. The level of availability of food in the environment will also encourage mothers to obtain and process these food ingredients into complementary foods for their babies (Kumalasari et al., 2015).

\section{The effect of posyandu on comple- mentary feeding practice}

The results showed that the posyandu contextual variables gave variations in the practice of giving complementary feeding by ICC= 28.01\%. In other words, variations in com- 
Fa'ni et al./ Integrated health post and complementary feeding practice

plementary feeding practice by $28.01 \%$ are influenced by posyandu. Table 4 shows that the ICC value in this study is greater than the rule of thumb rule of $8-10 \%$, so the contextual influence in this study is an important posyandu to note.

Posyandu is a basic health activity organized from, by and for the community assisted by health workers in a working area of the puskesnas, where this program can be carried out in hamlet halls, village halls, and other places that are easily visited by the community. Posyandu is a strategic step in the framework of developing the quality of Indonesian human resources in order to be able to develop and help themselves, so that their development needs to be promoted. To improve the development of posyandu as family planning and health services that are managed for and by the community with technical service support from officers, they need to grow, develop, need and be active (Sulistyorini, 2010).

Posyandu is one form of CommunityBased Health Efforts (UKBM) which is managed and organized from, by, for and with the community in the implementation of health development, in order to empower and provide facilities in obtaining basic health services so as to accelerate the reduction in maternal and infant mortality rates which are a the main purpose of posyandu. The specific objectives of the posyandu are to increase community participation in the implementation of primary health care efforts, increase crosssectoral roles, and increase the reach of basic health services. One of the activities of the posyandu is monitoring growth and development in infants. One of them is by monitoring and providing assistance to mothers about the provision of complementary food that is good and right so that the nutrition of infants and toddlers is still met according to the needs of each individual (Ministry of Health, 2011).
Based on the results of the study it can be concluded that there is a significant influence between birth weight of children, nutritional status of children, knowledge of complementary feeding, education, income, in complementary feeding practice. Variations at the posyandu level indicate contextual influences on the practice of giving complementary feeding.

\section{AUTHOR CONTRIBUTION}

Renidya Ashura Muttabi' Deya Fa'ni as the main researcher is as a research organizer, collecting research data, formulating research articles, and processing data. Yulia Lanti Retno Dewi was instrumental in preparing the background and analyzing research data. Isna Qadrijati plays a role in the formulation of the framework of thinking and research discussion.

\section{CONFLICT OF INTEREST}

There is no conflict of interest in this study.

\section{FUNDING AND SPONSORSHIP}

This study is self-funded.

\section{ACKNOWLEDGEMENT}

We would like to thank the UPT Puskesmas Ponjong I and posyandu cadres in the Ponjong sub-district area who have helped the data collection and mothers who have agreed to become study subjects.

\section{REFERENCE}

Asare BY, Preko JV, Baafi D, Dwumfour B (2018). Breastfeeding practices and determinants of exclusive breastfeeding in a cross-sectional study at a child welfare clinic in tema Manhean, Ghana. Int. Breastfeed. J, 13(12). https://doi.org/10.1186/s13006-018-0156-y

Barrera CM, Hamner HC, Perrine CG, Scanlon KS (2018). Timing of introduction of complementary foods to us infants, national health and nutrition exa-mina- 
Fa'ni et al./ Integrated health post and complementary feeding practice

tion survey 2009-2014. J Acad Nutr Diet, 118 (3):464-470. https://doi.org/10.101-6/j.jand.2017.10.020

Doub AE, Moding KJ, Stifter CA (2015). Infant and maternal predictors of early life feeding decisions the timing of solid food introduction. Elsevier, 92:261268. https://doi.org/10.1016/j.appet.2015.05.028

Dutta S, Singh B, Chessell L, Wilson J, Janes M, McDonald K, Shahid S, GardnerVA, Hjartarson A, Purcha M, Watson J, Boer CD, Gaal B, Fusch C (2015). Guidelines for feeding very low birth weight infants. Nutrients, 7:423-442. https://doi:10.3390/nu7010423

Ginting D, Sekawarna N, Sukandar H (2013). Pengaruh karakteristik faktor internal dan eksternal ibu terhadap pemberian mp-asi dini pada bayi usia $<6$ bulan di wilayah kerja puskesmas barus jahe kabupaten Karo provinsi Sumatera Utara (Influence of the characteristics of internal and external factors of the mother to the provision of early breastfeeding in infants aged $<6$ months in the working area of the new ginger health center in Karo district, North Sumatra province). Retrieved from http://pustaka.-unpad.ac.id/wpcontent/uploads/2013/o1/pustaka_unpad _pengaruh_karakteristik_faktor_inter nal.pdf

Helle C, Hillesund ER, Overby NC (2017). Early food for future health: a randomized controlled trial evaluating the effect of an ehealth intervention aiming to promote healthy food habits from early childhood. BMC Public Health, 17 (729). https://doi.org/10.-1186/s12966-018-0763-4

Helle C, Hillesund ER, Overby NC (2018). Timing of complementary feeding and associations with maternal and infant characteristics: a Norwegian crosssec- tional study. PLOS ONE, 13 (06). https://doi.org/10.1371/journal.pone.o 199455

Herber JS, Koletzko B, Fewtrell MS, Embleton ND, van Goudoever JB, Gruszfeld D, Lapillonne A, McNulty A, Szitanyi P (2018). Family education and training on infant feeding in the unit and after discharge. Retrieved from https://new-born-health-standards.org/-family-education-infant-fee-ding/

Heryanto E (2017). Faktor-faktor yang berhubungan dengan pemberian makanan pendamping ASI dini (Factors related to early supplementary breastfeeding). Jurnal Ilmu Kesehatan, 2 (2):141-152. Retrieved from http://ejournal.stikesaisyahac.id/-index.php/jika/

Iguacel I, Alvarez L, Cabero MA, Monje L, Moreno LA, Rodriguez M, Rivero M, et al. (2019). Rapid infancy weight gain during the com-plementary feeding period in a cohort of spanish infants. Journal Child and Adolescent Obesity, 2(1):63-67. https://doi.org/10.1080/25-74254X.2019.1651170

Kumalasari SY, Sabrian F, Hasanah O (2015). Faktor-faktor yang berhubungan dengan pemberian makanan pendamping asi dini (Factors related to early complementary feeding). JOM, 2(1).s https://jom.unri.ac.id/-index.php/JOMPSIK/article/view/5211

Koletzko B, Fewtrell MS, Domellöf M, Embleton N, Gruszfeld D, Lapillonne A, McNulty A, et al. (2018). Standards of nutritional practice. Retrieved from https://newborn-health-standards.org/standards-nutritional-practice/

Lestari MU, Lubis G, Pertiwi D (2015). Hubungan pemberian makanan pendamping asi (MP-ASI) dengan status gizi anak usia 1-3 tahun di kota Padang tahun 2012 (The relationship of complementary feeding (MP-ASI) with the 
Fa'ni et al./ Integrated health post and complementary feeding practice

nutritional status of children aged 1-3 years in the city of Padang in 2012). https://doi.org/10.25077-/jka.v3i2.83

Nauli DW (2012). Hubungan pemberian mpasi dini dengan kejadian penyakit infeksi pada bayi o-6 bulan di wilayah kerja puskesmas Sindar Raya kecamatan Raya Kahean kabupaten Simalungun tahun 2012 (The relationship of giving early $\mathrm{mp}$-ation with the incidence of infectious disease in infants o6 months in the working area of the Sindar Raya puskesmas Raya Raya Kahean sub-district Simalungun district in 2012). Retrieved from http://repository.usu.ac.id/bitstream/handle/123456789/37415/Cover.pdf;jsessionid=B3BD4DAEAB2FAE3B70Fo5B8DF30$\mathrm{C} 755 \mathrm{C}$

Nurzeza A, Larasati TA, Wulan D (2015). Hubungan tingkat pendidikan, pengetahuan dan kepercayaan ibu terhadap pemberian makanan pendamping asi (MP-ASI) pada bayi di bawah usia 6 bulan di desa Braja Sakti, kecamatan Way Jepara, kabupaten Lampung Ti-mur (Relationship between level of education, mother's knowledge and trust in complementary feeding (MP-ASI) for infants under 6 months of age in Braja Sakti village, Way Jepara sub-district, East Lampung district). Retrieved from https://juke.kedokteran.unila.ac.id/index.php/agro/article/view/1789
Putri AM (2013). Hubungan pemberian makanan pendamping ASI dengan status gizi bayi usia 7-12 bulan di posyandu puskesmas Singkil kabupaten Aceh Singkil (The relationship between complementary feeding and nutritional status of infants aged 7-12 months at the Posyandu Puskesmas Singkil, Aceh Singkil District). Retrieved from https://etd.-unsyiah.ac.id/index.php?p=show_detail\&id $=15859$

Walsh A, Kearney L, Dennis N (2015). Factors influencing first-time mothers' introduction of complementary foods: a qualitative exploration. BMC Public Health, 15:939. Retrieved from https://doi.org/10.1186-/s12889-0152250-z

Wardhani GK (2018). Correlation between provision of complementary feeding and nutritional status of infants 6-24 months in the Setabelan village Surakarta 2015. Jurnal Ilmiah Kesehatan Mediahusada, 7(2). Retrieved from http://docplayer.info/113937645-Hubu-ngan-pemberian-makanan-pendamping-asi-dengan-status-gizi-bayiusia-6-24-bulan-di-kelurahan-setabelan-kota-surakarta-tahun2015-.html WHO (2009). Infant and young child feeding: model chapter for textbooks for medical students and allied health professionals. Retrieved from https://www.who.int/maternal_child_adolescent/documents/9789241597494/en/ 